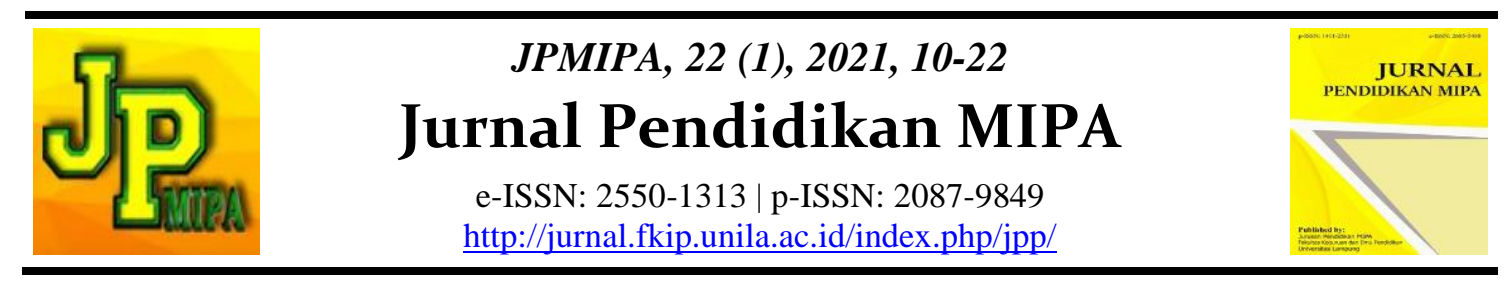

\title{
The Development of Test Instrument on The Excretion System to Measure Creative Thinking Skills
}

\author{
Ummu Maghfiroh, Lukman Nulhakim, Dwi Indah Suryani \\ Department of Science Education, Universitas Sultan Ageng Tirtayasa, Indonesia
}

\begin{abstract}
The creative thinking ability test instrument is a form tool to measure student creative thinking skills. This study aims to develop a creative thinking ability test instrument and determine is validity level. The research method used in developing the test instrument is the Borg and Gall development method (1983). The research instrument used in this study was a validation sheet. The results of this study indicate that the research and development process carried out by the researchers is a potential problem, data collection, planning, product design development, design validation, and design revision. The validity level of the creative thinking ability test instrument on the concept of the human excretion system that the researcher developed was in the valid category with a value of $76.94 \%$. The test instrument for the ability to think creatively on the concept of the human excretion system is valid for use in student trials.
\end{abstract}

Keywords: Test instrument, creative thinking, excretion system

Abstrak: Instrumen tes kemampuan berpikir kreatif merupakan bentuk alat untuk mengukur kemampuan berpikir kreatif siswa. Penelitian ini bertujuan untuk mengembangkan instrumen tes kemampuan berpikir kreatif dan mengetahui tingkat kevalidannya. Metode penelitian yang digunakan dalam mengembangkan instrumen tes adalah metode pengembangan Borg and Gall (1983). Instrumen penelitian yang digunakan dalam penelitian ini adalah lembar validasi. Hasil penelitian ini menunjukkan bahwa proses penelitian dan pengembangan yang dilakukan peneliti adalah potensi masalah, pengumpulan data, perencanaan, pengembangan desain produk, validasi desain, dan revisi desain. Tingkat kevalidan instrumen tes kemampuan berpikir kreatif pada konsep sistem ekskresi manusia yang peneliti kembangkan adalah pada kategori valid dengan nilai sebesar 76,94\%. Instrumen tes kemampuan berpikir kreatif pada konsep sistem ekskresi manusia tersebut valid untuk digunakan pada uji coba kepada siswa.

Kata kunci: Instrumen tes, berpikir kreatif, sistem ekskresi

\section{- INTRODUCTION}

The ability to think creatively is needed in the world of education to develop the potential of students to become creative humans. This is in line with the demands of competence in the 2013 curriculum (Ministry of Education and Culture, 2013) and learning abilities in the 21 st century, namely being able to implement science in scientific research, solve problems, and make creative works of everyday life through creative thinking skills. In addition, it is also in line with the daily life of students in keeping up with the times and technology where students are expected to be able to take advantage of their creative thinking skills in creating creative works.

Creative thinking skills are part of higher order thinking skills (HOTS) that students must have (Istiyono et al., 2014). Creative thinking skills are basically skills

Ummu Maghfiroh et al.

Email: ummumaghfiroh1@gmail.com
DOI: http://dx.doi.org/10.23960/jpmipa/v22i1.pp10-23

Received: 09 February 2021

Accepted: 25 March 2021 
that arise because they often solve problems using different methods (Kiryak \& Çalik, 2017). Creativity shows that all children have creative thinking skills at various levels (Turkmen \& Sertkahya, 2015). In the current information age, creative thinking is considered important for educated people to face a world that is changing rapidly (Anwar, et al., 2012). The ability to think creatively is the ability to think about new ideas in ways, methods, and solutions (Verlinden, 2005). Creative thinking is a thought process that is oriented towards good and correct answers that need to be trained to students because it can help students respond to a problem from various points of view and is able to generate many ideas in solving the problem (Kusumaningrum and Djukri, 2016; Perry and Karpova, 2017 ).

According to Elaine (2014), creative thinking is a habit of the mind trained by paying attention to intuition, turning on the imagination, revealing new possibilities, creating amazing perspectives, and generating unexpected ideas. Nuswowati et al. (2017) argued that creative thinking has four indicators, namely fluence is the ability to generate many ideas, flexibility is the ability to generate various ideas, originality, the ability to generate new original ideas, and elaboration is the ability to develop or add to ideas. to generate more detailed and innovative ideas. Creative thinking skills are skills to use creative ideas and techniques that are broadly unlimited; create new, useful ideas; describe, reconcile, analyze, and evaluate existing ideas to develop and maximize creative efforts (Putranta and Supahar, 2019). The creative thinking process requires openness and self-discipline, courage to take risks, and tolerance for differences.

In realizing the competency requirements in current and future curricula, appropriate tools are needed according to the criteria for creative thinking, one of which is through a test instrument. The test instrument is a measuring tool in the form of test questions to gather information about a person's abilities. Tests regarding creative thinking skills that have developed earlier are the test of divergent thinking, Torrance test of creative thinking verbal (Kim, 2006), tests for creative thinking-drawing production (TCT-DP), Packet's creativity assessment (Williams, 1980) and inventory khatena (Munandar, 2016). These tests are presented globally to measure the level of creative thinking of students.

The assessment instrument must meet the requirements of substance (content), construction and language and have evidence of empirical validity and produce scores that can be compared between schools, between regions and between nationalities (Minister of Education and Culture Regulation, 2016). In addition, standard assessment instruments must be valid, reliable, and free from irrational elements (Mardapi, Kumaidi \& Kartowarigan, 2011). The assessment model also needs to be considered, because it can affect the ability to think creatively and understand conceptual (Van den Berg, 2008). The right test instrument can motivate students to learn through appropriate creative thinking skills in everyday problems (Putranta \& Supahar, 2019).

There are not many researches regarding the development of a test of students' creative thinking abilities in learning, and so is the integration of concepts. Florida, et al. (2015) stated that there were still few questions that specifically trained students' creative thinking skills. This is in accordance with the research of Redhana (2015) which states that teachers are not aware of the existence of tests to measure students' creative thinking skills so that the teacher has never made the test. It is also in line with the conclusion of the results of the interview with the science teacher at SMP Unggulan Uswatun Hasanah, namely that they have not used integration in the preparation of questions, there is still a lack of the teacher's ability to develop questions with a creative 
thinking perspective, only using aspects of original thinking (suggesting new ideas / ideas) in making questions. Therefore, it is necessary to develop a creative thinking ability test instrument using integrated concepts. The integration of the concepts in question is a link between the main concepts and the supporting concepts (Murfiah, 2017). According to Putranta \& Supahar (2019), the way to improve creative thinking skills is to practice solving problems in life frequently. Then for the transfer of creativity skills, it can be done by authentic assignments by teachers at schools (Anwar et al., 2012). Creativity can be encouraged globally by stimulating creative thinking styles, applying divergent thinking processes involved in problem solving, and using various strategies to produce creative products (Rabanos and Torres, 2012).

The purpose of this study was to develop a creative thinking ability test instrument and determine its validity level. This test instrument can be used to measure and develop students' creative thinking skills, especially in the concept of the human excretion system at the junior high school level.

\section{- METHOD}

This study uses a research and development method which refers to the Borg and Gall development method with 10 stages of development. However, in this study, researchers only arrived at three stages, namely

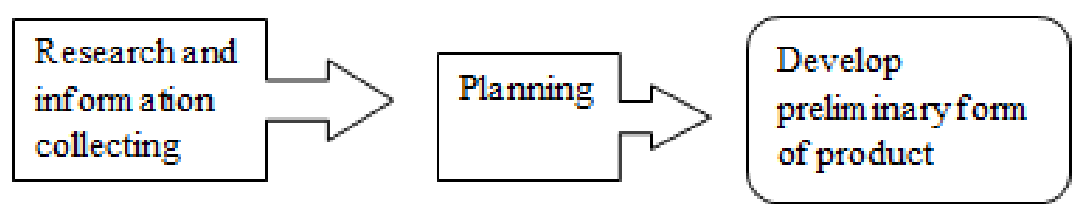

Figure 1. Research design modified from Borg \& Gall (1983)

The research design was accompanied by two development steps by Sugiyono (2017), namely design validation and design revision as well as steps to develop learning outcomes tests (Mardapi, 2018), starting from compiling test specifications, writing test questions, and analyzing test questions.

Thus, the research and development process that researchers carry out is potential problems, data collection, planning, product design development, design validation, and design revision. Activities at the potential problem stage and data collection are field studies and literature studies. The field study was carried out at SMP Negeri 3 Cilegon and SMP Unggulan Uswatun Hasanah. Meanwhile, design validation was carried out by two expert lecturers from FKIP Untirta science education and two expert teachers from SMP Negeri 3 Cilegon and SMP Unggulan Uswatun Hasanah. The validity used is logical validity which is validity based on the results of reasoning, which is tested by experts in their fields. Design validation experts are learning evaluation experts, material experts, and educators.

The collection of validation data from these experts used a test instrument validation questionnaire which included three aspects of assessment, including aspects of substance, construction, and language. The results of the questionnaire data obtained were processed qualitatively to obtain the percent value sought (NP) by means of the raw score obtained $(\mathrm{R})$ divided by the ideal maximum score (SM) then multiplied by $100 \%$ as a fixed number (Purwanto, 2013). The qualitative calculation results are interpreted into the validity criteria using intervals, including: (1) $81 \%-100 \%=$ very 
valid, (2) $61 \%-80 \%=$ valid, (3) $41 \%-60 \%=$ quite valid, (4) $21 \%-40 \%=$ less valid, (5) $0 \%-20 \%=$ very less valid (modification from Riduwan, 2012)

\section{- RESULT AND DISCUSSION}

The research and development process that is carried out is potential problems, data collection, planning, product design development, design validation, and design revision.

\section{1) Potentials and Problems}

Potential and problems were obtained from the results of field studies, namely the results of interviews with junior high school science teachers regarding the assessment of learning outcomes and students' creative thinking skills in schools. The results of the analysis of the interview data are as follows: (a) In the preparation of questions, they have not used cohesiveness such as concept cohesiveness. This is because the curriculum in schools has not fully used integration in learning, especially in the assessment of cognitive aspects. (b) The teacher's ability is still lacking in developing questions that contain aspects of creative thinking. This is due to the lack of continuous procurement of training in creative thinking questions arrangement. Ongoing training, which is about the preparation of critical thinking questions and learning media. (c) In making questions, new teachers use one aspect of creative thinking, namely the aspect of original thinking (suggesting new ideas / ideas). This is because the original aspect is easier and identical in reflecting the ability to think creatively, which also corresponds to the phase of student cognitive development.

\section{2) Data Collection}

Data Collection obtained from literature studies on tests of creative thinking skills and curriculum. The literature study conducted was an analysis of tests of creative thinking skills and an analysis of the Class VIII SMP Science learning curriculum.

\section{a. Analysis of creative thinking ability test questions}

The tests regarding creative thinking skills that are available are the test of divergent thinking, the Torrance test of creative thinking verbal (Torrance in Kim, 2006), the test for creative thinking-drawing production (TCT-DP), and the creativity assessment packet (Williams, 1980). The creative thinking ability test that will be developed is based on the Torrance test of verbal creative thinking. This is because to support and develop questions made by the teacher, which only uses one aspect of creative thinking, namely the aspect of original thinking. Original thinking that is raised by the teacher in the question is in the form of expressing new ideas / ideas. The characteristics of the questions express ideas in the form of preventive solutions and efforts to maintain health and care for each other.

\section{b. Analysis of the class VIII SMP science learning curriculum}

The curriculum used at SMPN 3 Cilegon and SMP Unggulan Uswatun Hasanah Cilegon is the 2013 curriculum. The demands of the two basic competencies of the excretory system and addictive substances in the curriculum are to analyze disturbances in the excretory system as well as efforts to maintain the health of the system and introduce a hazardous substance to minimize its presence in body. The assessment of the two basic competencies is still independent, there is no integration that supports 
each other. In fact, the concept of the excretory system and the concept of addictive substances have interrelated power to support each other.

\section{c. Student Needs}

Students have the right to get educational services according to their talents, interests, and abilities. The rights of these students can be fulfilled through educational units operated by educators, namely teachers. Teachers are required to create an educational atmosphere that is meaningful, fun, creative, dynamic, and dialogical (The Law of The Republic of Indonesia Number 20 of 2003). The talents, interests, and abilities that students want to develop can be through a creative educational atmosphere where starting from honing and developing students' creative thinking skills so that students can be skilled in creating or solving problems. This is in line with the results of interviews with teachers, namely creative students in terms of asking questions, answers, and expressing new ideas. Creative possessed by these students reflects that students have reached the ability to think creatively, namely thinking fluently and thinking original. In order to support and hone students 'creative thinking skills, it takes practice questions that have characteristics of developing students' creative thinking abilities.

\section{d. Planning}

The data collected from the data are analyzed, then the aspects of creative thinking, competency outcomes, and integration are determined which will be used in the preparation of test questions. The following is an explanation of the aspects of creative thinking, competency outcomes, and cohesiveness that the authors use:

Aspects and indicators of creative thinking in developing test instruments

The creative thinking ability test used is the Torrance test of creative thinking verbal. The aspects of creative thinking skills used are 4 aspect scales with 6 Torrance sub tests and 8 indicators which are described in table 2 below:

Table 2. Aspects and indicators of creative thinking ability test

\begin{tabular}{|c|c|c|c|}
\hline No. & $\begin{array}{l}\text { Aspects of } \\
\text { Creative } \\
\text { Thinking }\end{array}$ & Torrance sub test & Creative Thinking Indicators \\
\hline \multirow[t]{2}{*}{1.} & Think fluently & $\begin{array}{l}\text { Asking questions / } \\
\text { statements }\end{array}$ & $\begin{array}{l}\text { Come up with lots of ideas, } \\
\text { answers, problem solving, or } \\
\text { questions }\end{array}$ \\
\hline & & $\begin{array}{l}\text { a. Guess cause and } \\
\text { effect } \\
\text { b. Proposition of } \\
\text { advantages and } \\
\text { disadvantages }\end{array}$ & $\begin{array}{l}\text { a. Provide many ways or } \\
\text { suggestions for doing things in } \\
\text { guessing cause or effect. } \\
\text { b. Provide many ways or } \\
\text { suggestions for doing various } \\
\text { things in terms of profit and } \\
\text { loss. }\end{array}$ \\
\hline 2. & Think flexible & & $\begin{array}{l}\text { Generate a variety of ideas, } \\
\text { answers, or questions. } \\
\text { Can see a problem from different } \\
\text { points of view. }\end{array}$ \\
\hline
\end{tabular}

3. Original Giving birth to new Being able to give birth to new 


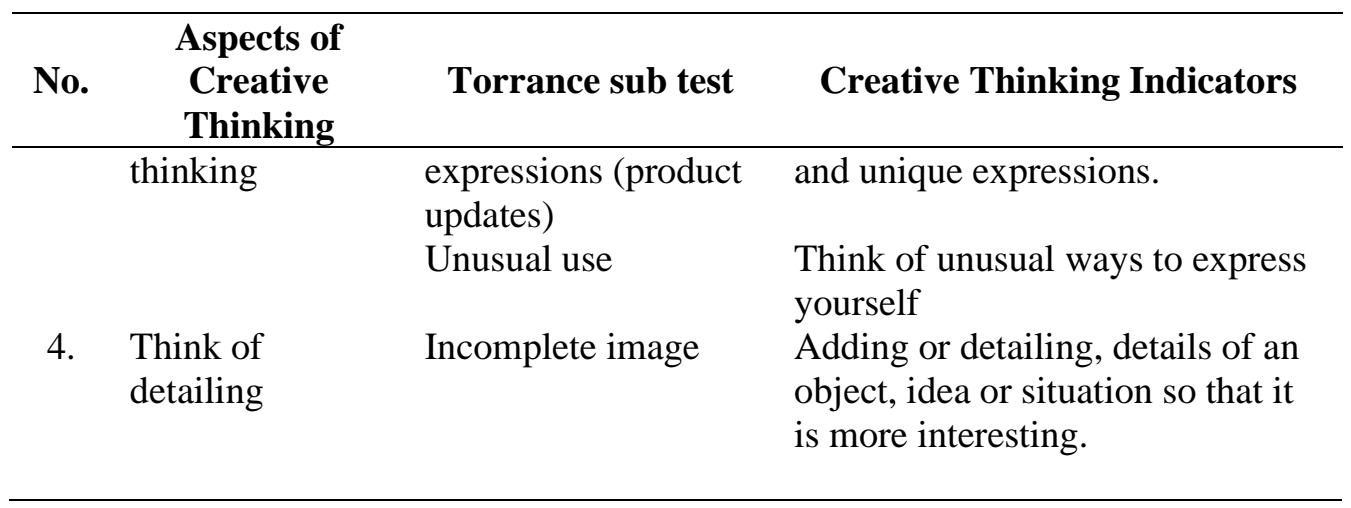

Competency achievements in the development of test instruments

The following competency achievements are indicators that already exist between the excretion system concept and the concept of addictive substances.

Table 3. Analysis of science curriculum for class viii of junior high school

Basic competencies

3.10. Analyze the excretory system in humans and understand disorders of the excretory system and efforts to maintain the health of the excretory system.
Indicators of competence achievement

3.10.1. Describe the parts of the organs for the removal of waste substances in the excretory organs including the waste products for consumption of

Terms addictive substances.

3.10.2. Identify the function of the excretory system organs after consuming addictive substances.

3.10.3. Describe a schematic of the formation process in the excretory organs.

3.10.4. Analyzing the relationship between structure and function in the excretory organs.

Main

3.10.5 Understand disorders of the excretory system.

3.10.6 Understand the efforts to maintain the health of the excretory system.

3.10.7 Designing a healthy lifestyle to maintain the excretory system.

3.10.8 Formulate a hypothesis 


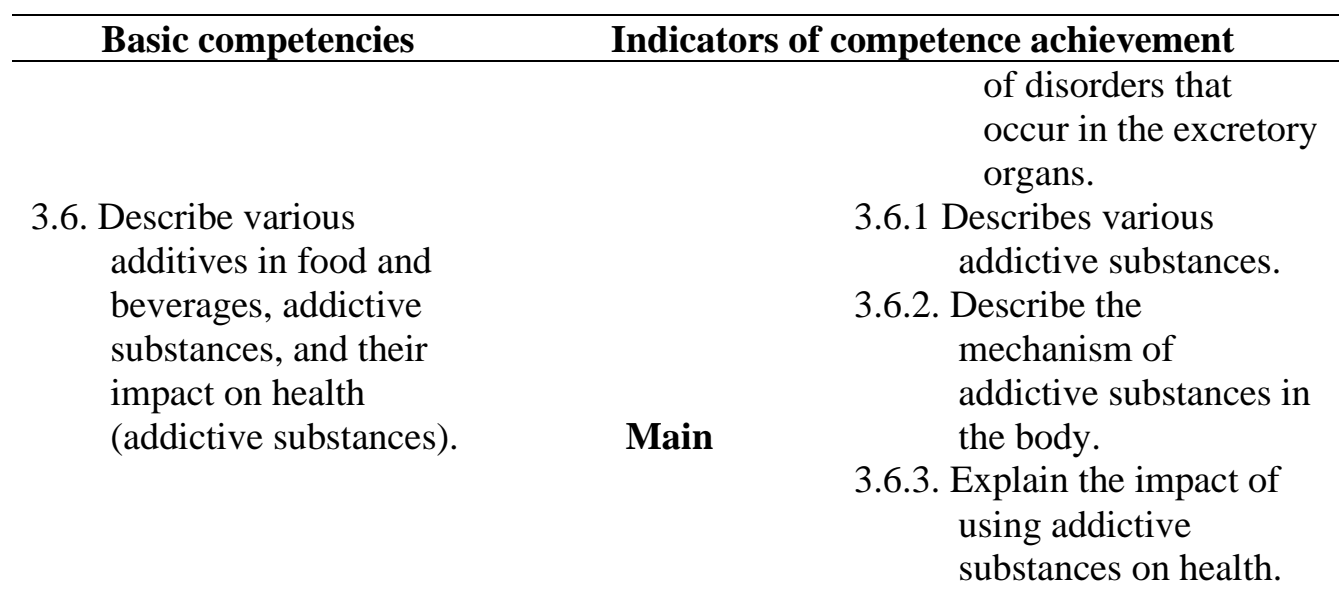

The integrated model in developing test instruments

The concept used by researchers is the concept of the human excretion system. The concept uses connected integration by selecting KD 3.10 as the main KD and is linked to KD 3.6, the concept of addictive substances. The choice of this concept is seen from the characteristics of the two basic competencies chosen which have a fairly important role, namely regarding maintaining the health and stability of the body's excretory system and introducing a hazardous substance to minimize its presence in the body. This is also supported by the opinion of the science teacher from SMPN 3 Cilegon, namely that this concept has characteristics in terms of inviting students to care about the health of organs and the excretory system.

After determining the three, a grid of creative thinking skills tests was carried out. The grid includes basic competencies, competency achievement indicators, creative thinking aspects, creative thinking aspect indicators, and question indicators. The grid is arranged by linking the concept of the excretory system and the concept of addictive substances to the achievement indicators and question indicators. The integration of these indicators must contain and achieve indicators of the creative thinking aspects used.

Product design development

Product design development is the process of designing a product, namely writing questions and test answer rubrics. Writing test questions is the process of clearly describing the indicators on the grid into question questions. The development of a test instrument for the ability to think creatively on the concept of human excretion systems and addictive substances consists of 30 items in description, including 10 questions for fluent thinking, 10 questions for flexible thinking, 6 questions for original thinking, and 4 questions for detailed thinking. The test questions are made according to the indicators of competency achievement and creative thinking indicators. Test questions are arranged based on indicators of competency achievement. The test answer rubric was created using a score range of 3,2,1 on each item. Score 3 is the highest score while score 1 is the lowest score. The value can be seen from the complexity of the answer keywords. 
Design validation

Validation activities are carried out to determine the success rate of design making. If there are deficiencies, then corrections are made. The draft of the creative thinking ability test instrument is logically validated by experts in their fields, including two lecturers from the Science Education Department and two science teachers from SMPN 3 Cilegon and SMP Unggulan Uswatun Hasanah Cilegon using a validation questionnaire. The following are the results of the validity per item test instrument from the experts:

a. Expert Lecturer

Table 4. Validity results per item question by expert lecturers

\begin{tabular}{cclcl}
\hline \multirow{2}{*}{ No } & \multicolumn{2}{c}{ Expert 1 } & \multicolumn{2}{c}{ Expert 2 } \\
\cline { 2 - 5 } & Score & Annotation & Score & Annotation \\
\hline 1. & $80.00 \%$ & Valid & $83.33 \%$ & Very Valid \\
2. & $78.33 \%$ & Valid & $81.67 \%$ & Very Valid \\
3. & $78.33 \%$ & Valid & $80.00 \%$ & Valid \\
4. & $80.00 \%$ & Valid & $81.67 \%$ & Very Valid \\
5. & $80.00 \%$ & Valid & $81.67 \%$ & Very Valid \\
6. & $76.67 \%$ & Valid & $80.00 \%$ & Valid \\
7. & $76.67 \%$ & Valid & $80.00 \%$ & Valid \\
8. & $78.33 \%$ & Valid & $80.00 \%$ & Valid \\
9. & $78.33 \%$ & Valid & $81.67 \%$ & Very Valid \\
10. & $76.67 \%$ & Valid & $81.67 \%$ & Very Valid \\
11. & $71.67 \%$ & Valid & $80.00 \%$ & Valid \\
12. & $75.00 \%$ & Valid & $81.67 \%$ & Very Valid \\
13. & $76.67 \%$ & Valid & $80.00 \%$ & Valid \\
14. & $80.00 \%$ & Valid & $76.67 \%$ & Valid \\
15. & $76.67 \%$ & Valid & $80.00 \%$ & Valid \\
16. & $73.33 \%$ & Valid & $61.67 \%$ & Valid \\
17. & $75.00 \%$ & Valid & $81.67 \%$ & Very Valid \\
18. & $76.67 \%$ & Valid & $80.00 \%$ & Valid \\
19. & $75.00 \%$ & Valid & $81.67 \%$ & Very Valid \\
20. & $76.67 \%$ & Valid & $78.33 \%$ & Valid \\
21. & $73.33 \%$ & Valid & $78.33 \%$ & Valid \\
22. & $76.67 \%$ & Valid & $81.67 \%$ & Very Valid \\
23. & $76.67 \%$ & Valid & $80.00 \%$ & Valid \\
24. & $80.00 \%$ & Valid & $81.67 \%$ & Very Valid \\
25. & $78.33 \%$ & Valid & $81.67 \%$ & Very Valid \\
26. & $76.67 \%$ & Valid & $80.00 \%$ & Valid \\
27. & $80.00 \%$ & Valid & $78.33 \%$ & Valid \\
28. & $80.00 \%$ & Valid & $78.33 \%$ & Valid \\
29. & $76.67 \%$ & Valid & $80.00 \%$ & Valid \\
30. & $80.00 \%$ & Valid & $78.33 \%$ & Valid \\
\hline & & & & \\
\hline
\end{tabular}

Table 4 shows the percentage of validation results by two expert lecturers on 30 items developed with 12 assessment components divided into three aspects, namely the substance aspect, the construction aspect, and the language aspect. After analyzing the validation of the items by expert lecturers, it is known that the 30 items developed reached the intervals of $61 \%-80 \%$ and $81 \%-100 \%$. The percentage of the final score that reaches the interval of $61 \%-80 \%$ on the items is declared valid. The test items that 
are declared valid are questions number $3,6,7,8,11,13,14,15,16,18,20,21,23,26$, $27,28,29,30$. The percentage of the final score that reaches interval $81 \%-100 \%$ on the item then the question is declared very valid. In questions number $1,2,4,5,9,10,12$, $17,19,22,24,25$ obtained different validity results between expert lecturers 1 and expert lecturers 2. However, the questions on that number are still included in the category valid.

b. Expert Teacher

Table 5. Validity results per item question by expert teachers

\begin{tabular}{|c|c|c|c|c|}
\hline \multirow[t]{2}{*}{ No } & \multicolumn{2}{|c|}{$\begin{array}{c}\text { Expert } 1 \\
\text { (SMPU Uswatun Hasanah Cilegon) }\end{array}$} & \multicolumn{2}{|c|}{$\begin{array}{c}\text { Expert 2 } \\
\text { (SMPN } 3 \text { Cilegon) }\end{array}$} \\
\hline & Score & Annotation & Score & Annotation \\
\hline 1. & $78.33 \%$ & Valid & $68.33 \%$ & Valid \\
\hline 2. & $93.33 \%$ & Very Valid & $78.33 \%$ & Valid \\
\hline 3. & $93.33 \%$ & Very Valid & $66.67 \%$ & Valid \\
\hline 4. & $78.33 \%$ & Valid & $68.33 \%$ & Valid \\
\hline 5. & $91.67 \%$ & Very Valid & $83.33 \%$ & Very Valid \\
\hline 6. & $91.67 \%$ & Very Valid & $68.33 \%$ & Valid \\
\hline 7. & $91.67 \%$ & Very Valid & $66.67 \%$ & Valid \\
\hline 8. & $91.67 \%$ & Very Valid & $68.33 \%$ & Valid \\
\hline 9. & $95.00 \%$ & Very Valid & $65.00 \%$ & Valid \\
\hline 10. & $95.00 \%$ & Very Valid & $63.33 \%$ & Valid \\
\hline 11. & $96.67 \%$ & Very Valid & $68.33 \%$ & Valid \\
\hline 12. & $96.67 \%$ & Very Valid & $76.67 \%$ & Valid \\
\hline 13. & $96.67 \%$ & Very Valid & $75.00 \%$ & Valid \\
\hline 14. & $96.67 \%$ & Very Valid & $75.00 \%$ & Valid \\
\hline 15. & $96.67 \%$ & Very Valid & $68.33 \%$ & Valid \\
\hline 16. & $95.00 \%$ & Very Valid & $80.00 \%$ & Valid \\
\hline 17. & $95.00 \%$ & Very Valid & $80.00 \%$ & Valid \\
\hline 18. & $90.00 \%$ & Very Valid & $68.33 \%$ & Valid \\
\hline 19. & $76.67 \%$ & Valid & $70.00 \%$ & Valid \\
\hline 20. & $93.33 \%$ & Very Valid & $68.33 \%$ & Valid \\
\hline 21. & $78.33 \%$ & Valid & $61.67 \%$ & Valid \\
\hline 22. & $96.67 \%$ & Very Valid & $61.67 \%$ & Valid \\
\hline 23. & $80.00 \%$ & Valid & $65.00 \%$ & Valid \\
\hline 24. & $91.67 \%$ & Very Valid & $76.67 \%$ & Valid \\
\hline 25. & $95.00 \%$ & Very Valid & $65.00 \%$ & Valid \\
\hline 26. & $95.00 \%$ & Very Valid & $71.67 \%$ & Valid \\
\hline 27. & $78.33 \%$ & Valid & $66.67 \%$ & Valid \\
\hline 28. & $78.33 \%$ & Valid & $73.33 \%$ & Valid \\
\hline 29. & $93.33 \%$ & Very Valid & $68.33 \%$ & Valid \\
\hline 30. & $91.67 \%$ & Very Valid & $66.67 \%$ & Valid \\
\hline
\end{tabular}

Table 5 shows the percentage of validation results by two expert lecturers on 30 items developed with 12 assessment components which are divided into three aspects, namely the substance aspect, the construction aspect, and the language aspect. After analyzing the validation of the items by the teacher, it is known that the 30 items developed reached the intervals of $61 \%-80 \%$ and $81 \%-100 \%$. The percentage of the final score that reaches the interval of $61 \%-80 \%$ on the items is declared valid. The test items that were declared valid were questions number 1, 4. 19, 21, 23, 27, 28. The 
percentage of the final score that reached the $81 \%-100 \%$ interval on the questions was declared very valid. The test items that were declared very valid were question number 5.In questions number $2,3,6,7,8,9,10,11,12,13,14,15,16,17,18,20,22,24,25$, 26, 29, 30 obtained different validity results between expert teacher 1 and expert teacher 2. However, the questions on that number are still included in the valid category.

The results of the validity of the design of the creative thinking ability test instrument can be seen in table 6 below:

Table 6. Results of the validity of the instrument based on the judgement of evaluators

\begin{tabular}{ccccccc}
\hline $\begin{array}{c}\text { Aspects of the } \\
\text { assessment }\end{array}$ & \multicolumn{9}{c}{ Evaluator } & Score & $\begin{array}{c}\text { Percentage } \\
\text { score }\end{array}$ \\
\cline { 2 - 5 } Material & 15 & 16 & III & IV & & 17 \\
Contruction & 31 & 35 & 42 & 27 & 135 & $75.00 \%$ \\
Language & 20 & 20 & 22 & 20 & 82 & $82.00 \%$ \\
Total & 66 & 71 & 81 & 59 & 277 & \\
Final Score (\%) & 73.33 & 78.89 & 90 & 65.56 & 76.94 & \\
Information & Valid & Valid $\quad$ Very & Valid & Valid & & \\
Average & & 76.94 (Valid) & & & $77.33 \%$ \\
\hline
\end{tabular}

Notes: Evaluator I, II, III, IV are Expert Lecturer 1, Expert Lecturer 2, Expert Teacher 1, and Expert Teacher 2 respectively

Table 6 shows the results of the data processing of the validity value of the test instrument design from each expert. The validity value obtained from the experts varies, but the average result reaches $76.94 \%$ which is still included in the valid category. The average value of the percentage of the test instrument design based on the aspects of all experts is $77.33 \%$ which is included in the valid category.

Revision design

Suggestions from the validation results are used to improve and perfect the test instrument design being developed. Suggestions for improvement from experts can be seen in table 7 below.

Table 7. Suggestions for improvements

\begin{tabular}{ccll}
\hline No. & \multicolumn{1}{c}{ Adviser } & \multicolumn{1}{c}{ Suggestion } & \multicolumn{1}{c}{ Revision } \\
\hline 1. & Expert Lecturer 1 & $\begin{array}{l}\text { There is still a relationship } \\
\text { between one problem and } \\
\text { another. }\end{array}$ & $\begin{array}{l}\text { The questions are not related to } \\
\text { each other. }\end{array}$ \\
2. Expert Lecturer 2 & $\begin{array}{l}\text { Images / table data / text } \\
\text { readings are given a clear } \\
\text { identity or title. } \\
\text { Avoid using the word } \\
\text { under / over in the } \\
\text { question, use identity to } \\
\text { refer. } \\
\text { Adjust the question } \\
\text { indicator with the } \\
\text { competency achievement } \\
\text { indicator. } \\
\text { Include the integrity of }\end{array}$ & $\begin{array}{l}\text { KD } \\
\text { added with the title. }\end{array}$ & $\begin{array}{l}\text { In question questions that have } \\
\text { pictures / tables / text, you have } \\
\text { used the identity of the image / } \\
\text { table / text to refer. } \\
\text { The question indicator is in } \\
\text { accordance with the competency } \\
\text { achievement indicator }\end{array}$ \\
& & The integration of the concept
\end{tabular}




\begin{tabular}{|c|c|c|c|}
\hline No. & Adviser & $\begin{array}{c}\text { Suggestion } \\
\end{array}$ & $\begin{array}{c}\text { Revision } \\
\end{array}$ \\
\hline \multirow{3}{*}{4.} & \multirow{3}{*}{ Expert Teacher 2} & $\begin{array}{l}\text { into the competency } \\
\text { achievement indicators. }\end{array}$ & $\begin{array}{l}\text { has been included in the } \\
\text { competency achievement } \\
\text { indicators. }\end{array}$ \\
\hline & & $\begin{array}{l}\text { The images, text, and } \\
\text { tables used as stimuli will } \\
\text { match the questions on the } \\
\text { items. }\end{array}$ & $\begin{array}{l}\text { Pictures, text, and tables as } \\
\text { stimuli have been adjusted to the } \\
\text { questions. }\end{array}$ \\
\hline & & $\begin{array}{l}\text { The stimulus in the form of } \\
\text { text must be complex in } \\
\text { information according to } \\
\text { the question. }\end{array}$ & $\begin{array}{l}\text { Information has been complexed } \\
\text { according to the questions }\end{array}$ \\
\hline
\end{tabular}

The ability to think creatively is a competency to be achieved in the current curriculum as well as in the 21 st century learning, it is very necessary to be prepared. These competency demands must be followed by the provision of valid tools to measure and develop students' creative thinking. This creative thinking ability must be measured and developed through appropriate tests. The development of this creative thinking ability test instrument can help educators in the field to measure and develop students' creative thinking. Therefore, the development of a creative thinking ability test instrument is very important in order to be able to prepare students to think in generating new ideas in terms of methods, methods, or solutions.

The results of the validity per item show that the 30 items of the developed test instrument can be used to be tested on students, because they meet the standard requirements for the assessment instrument through the three aspects used. This is in line with Permendikbud (2016) which states that the assessment instruments used by education units in final examination assessments must meet the requirements of substance, construction, and language through validation from experts in their fields. Based on the aspect of the assessment which obtained a percentage of $75 \%$ in the material and construction aspects as well as $82 \%$ in the language aspect indicated that the test instruments developed were good. These three aspects play an important role in the success of making a test, namely in terms of the achievement of the measured indicators, clarity of sentences and test presentation, and the use of good, correct and communicative language according to the level of student development.

\section{- CONCLUSION}

Based on the research results obtained, it can be concluded that the research and development process carried out by researchers is a potential problem, data collection, planning, product design development, design validation, and design revision. The validity level of the creative thinking ability test instrument on the concept of the human excretion system that the researcher developed was in the valid category with a value of $76.94 \%$. Based on these results, the test instrument for the ability to think creatively on the concept of the human excretion system developed is valid for use in student trials. There is a limitation in this research, namely the creative thinking ability test instrument on the concept of the human excretion system developed only up to the design revision stage and only on certain concepts so it is necessary to follow up in this development research. 


\section{- REFERENCES}

Anwar, M. N., Aness, M., Khizar, A., Naseer, M., \& Muhammad, G. (2012). Relationship of creative thinking with the academic achievements of secondary school students. International Interdisciplinary Journal of Education, 1(3), 44-47.

Borg, W. R. \& Gall, M. D. (1983). Educational Research: An introduction. 4th Ed. New York: Longman, Inc.

Elaine, B. J. (2014) Contextual Teaching \& Learning. Bandung: Kaifa.

Florida, R., Charlotta M., \& Karen K. (2015). The Global Creativity Index. Rotman: The Martin Prosperity Institute.

Istiyono, E., Mardapi, D., \& Suparno. (2014). Development of high physical thinking skills (PysTHOTS) development students in high school. Jurnal Penelitian dan Evaluasi Pendidikan, 18(1), 1-12.

Kementrian Pendidikan dan Kebudayaan. (2013). Kerangka Dasar Kurikulum 2013. Jakarta: Kementrian Pendidikan dan Kebudayaan Direktorat Jenderal Pendidikan Dasar.

Kim, K. H. (2006). Can we trust creativity test?: A Review of the Torrance Test of Creative Thinking (TTCT). Creativity Research Journal, 18(1), 3-14.

Kiryak, Z., \& Çalik, M. (2017). Improving grade 7 students' conceptual understanding of water pollution via common knowledge construction model. International Journal of Science and Mathematics Education, 1(1), 1-22.

Kusumaningrum, S., \& Djukri, D. (2016). Development of project based learning $(\mathrm{PjBL})$ learning tools to improve skills in the process of science and creativity. Jurnal Inovasi Pendidikan IPA, 2(2), 241-251.

Mardapi, D., Kumaidi. \& Kartowagiran, B. (2011). Pengembangan instrumen pengukur hasil belajar nirbias dan terskala baru. Jurnal Penelitian dan Evaluasi Pendidikan 15(2): 326-341.

Mardapi, D. (2018). Teknik Penyusunan Instrumen Tes dan Non tes. Yogyakarta: Nuha Medika.

Munandar, U. (2016). Pengembangan Kreativitas Anak Berbakat. Jakarta: Rineka Cipta.

Murfiah, U. (2017). Pembelajaran Terpadu (Teori \& Praktik Terbaik di Sekolah). Bandung: PT Refika Aditama.

Nuswowati, M. et al. (2017). Implementation of problem-based learning with green chemistry vision to improve creative thinking skill and students' creative actions. Jurnal Pendidikan IPA Indonesia, 6(2), 221-228.

Peraturan Menteri Pendidikan dan Kebudayaan Republik Indonesia Nomor 23 tentang Standar Penilaian Pendidikan. 2016. Jakarta: Mendikbud.

Perry, A., \& Karpova, E. (2017). Efficacy of teaching creative thinking skills: A comparison of multiple creativity assessments. Thinking Skills and Creativity, $1(2), 1-25$.

Purwanto, M. N. (2013). Prinsip-prinsip dan Teknik Evaluasi Pengajaran. Bandung: PT. Rosdakarya.

Putranta, H. and Supahar. (2019). Development of Physics-Tier Test (PysTT) to measure students' conceptual understanding and creative thinking skill: A qualitative synthesis. Journal For The Education of Gifted Young Scientists, 7(3), 747-775. 
Rabanos, N. L and Torres, P. A. (2012). Effects of a program for developing creative thinking skills. Electronic Journal of Research in Educational Psychology, 10(3), $1139-1158$.

Redhana, I W. (2015). Pengembangan Tes Keterampilan Berpikir Kreatif. Jurnal Pendidikan dan Pengajaran, 48(1-3), 27-34.

Riduwan. (2012). Dasar-dasar Statistika. Bandung: Alfabeta.

Sugiyono. (2017). Metode Penelitian Kuantitatif, Kualitatif, dan R\&D. Bandung: CV. Alfabeta.

Turkmen, H. and Sertkahya, M. (2015). Creative thinking skills analyzes of vocational high school students. Journal of Education and Instructional Students in The World, 5(10), 74-84.

Van den Berg, G. (2008). The use of assessment in the development of higher-order thinking skills. Africa Education Review, 1(2), 279-294.

Verlinden, J. (2005). Critical Thinking and Everyday Argument. Belmont, CA: Wadsworth/ Thomson Learning, Inc.

Williams, F. (1980). Creativity Assessment Packet. Buffalo, NY: DOK. 